\title{
REFRAMING SOVEREIGNTY? SUB-STATE NATIONAL SOCIETIES AND CONTEMPORARY CHALLENGES TO THE NATION-STATE
}

\author{
STEPHEN TIERNEY*
}

\section{INTRODUCTION}

Over the past 30 years, sub-state national societies in a number of developed liberal democracies-particularly Quebec, Catalonia, and Scotland within Canada, Spain, and the United Kingdom respectively - have both reasserted their national distinctiveness and demanded recognition of it in constitutional terms. ${ }^{1}$ This re-emergence of sub-state national sentiment within industrially advanced States, and the struggle for constitutional change which has accompanied it, are considered by many observers to be strangely incongruous at a time of economic and cultural 'globalization' where the power of the nationState itself seems to be waning. ${ }^{2}$ Why do sub-state nations, the common refrain asks, seek statehood when the very concept of State sovereignty is losing its meaning? This article will argue, however, that the rise of sub-state nationalism even at a time when the resilience of State sovereignty is itself coming into question, is in fact not as paradoxical as it might at first appear, at least insofar as this process is taking place within developed democracies. ${ }^{3}$ It will be contended that the elaborate constitutional programmes which are now being advanced by sub-state nationalist movements for the reform of their respective host States are in many respects informed by, and reflective of, wider transformations in the patterns of State sovereignty.

The term 'sovereignty' is of course highly elusive, and in order to understand how it is used by sub-state nationalists in debates concerning the nature of the contemporary State, it is important to note how parties to these debates use sovereignty in a holistic way, embracing both its legal and political dimen-

* School of Law, University of Edinburgh.

1 This phenomenon has been termed by some 'neo-nationalism': M Keating Plurinational Democracy: Stateless Nations in a Post-Sovereignty Era (OUP Oxford 2001); K McRoberts Misconceiving Canada: The Struggle for National Unity (OUP Toronto 1997) 55; D McCrone 'Neo-Nationalism in Stateless Nations' (2001) Scottish Affairs 3-13; T Nairn The Break-Up of Britain: Crisis and Neo-Nationalism (New Left Books London 1977).

2 For Thomas Franck the phenomenon of neo-nationalism has been termed 'post-modern neotribalism': T Franck Fairness in International Law and Institutions (OUP Oxford 1995) 140-1; and for Michael Ignatieff, it is 'the narcissism of minor differences': 'The Narcissism of Minor Differences' in R Beiner (ed) Theorizing Nationalism (State University of New York Press Albany 1999) 91-102.

3 This study is restricted to a specific set of liberal democracies and the author makes no claim as to whether or not this analysis might be applied more generally to other cases of sub-state nationalism.

[ICLQ vol 54, January 2005 pp 161-183] 
sions. Here the recent work of Martin Loughlin is illuminating. Loughlin defines sovereignty as possessed of two different dimensions - 'competence' and 'capacity' - which encapsulate, respectively, the concept's legal and political elements. In other words, 'competence' represents 'authority' in a juridical sense, while 'capacity' embodies a more politicized conceptualization of pragmatic 'power'. ${ }^{4}$ This is a helpful model to apply to contemporary nationalism because we can observe in the praxis of sub-state nationalists precisely this combination of the legal and the political; each element is combined inextricably in the rhetoric with which these constitutional actors contest traditional narratives of State sovereignty. A second feature of this holistic conception of sovereignty is that by eliding the idea of legal authority and political power, it envisages sovereignty as being relational in nature: as Loughlin would have it, sovereignty is 'generated as a product of the political relationship between the people and the state'. 5 Again this relational idea features in the discourse of sub-state nationalists. For them sovereignty has a relational essence, but they demand that, when used to describe a multinational democracy, the relationship metaphor be made more complex in order to encapsulate the idea of 'the people' in a pluralistic way; sovereignty within a multinational State cannot be posited merely as the 'relationship between the people and the State', rather it must be a relationship between the peoples who together compose the State, and the State itself. The relational idea of sovereignty therefore must be one which is flexible enough to accommodate a plurality of peoples or demoi, each of which might bring with it a differing vision and a variegated set of claims concerning where sovereignty lies within the State.

One common myth which will be challenged in this article is the notion that the dominant nationalist voices within territories such as Catalonia, Quebec, and Scotland are in fact 'separatist' ones. In fact, sub-state national societies are, with their new visions of what sovereignty can and does mean, presenting very complex claims to greater autonomy and enhanced recognition within the State, while at the same time attempting to negotiate some measure of discrete personality within the international institutions to which the State belongs; these aspirations therefore represent a deeply ambivalent strategy of operating more effectively inside, and when the opportunity avails itself and is attractive, partly beyond, the nation-State. As such, these territories demonstrate in many ways that they are fully engaged with the modern challenges which face any polity in an age of 'late sovereignty', where the power of the nation-State is declining through the influence of international normative sites, but where, through playing a full role within these fora, territorial polities can yet retain considerable influence. ${ }^{6}$

Therefore, contemporary sub-state national demands for better constitu-

\footnotetext{
${ }^{4}$ M Loughlin The Idea of Public Law (OUP Oxford 2003) 82.

5 ibid 70 .

6 The term 'late sovereignty' suggests that the age of State sovereignty, even within the
} 
tional accommodation must be located within the context of a global political and legal environment which is itself rapidly changing. As Keating suggests: 'We are heading for a new, differentiated, asymmetrical political order in which the old constitutional categories are losing their meaning.'7 As they observe external challenges to the nation-State, sub-state national societies situate their own constitutional aspirations within this environment. It is in this context that their core aims take on an increasingly international flavour. For example: the goal of enhanced constitutional autonomy for the society's territorial space now makes reference not only to the State but also to membership of international organizations; ${ }^{8}$ the search for improved institutional representation for the society now targets not only the central State but also the international community ${ }^{9}$ and the desire for general recognition of the society's 'national' status similarly looks to both State and international actors for a response. ${ }^{10}$

In Section 2 this article will demonstrate how sub-state nationalism within 'plurinational' States relates to wider contemporary challenges to traditionally rendered accounts of the 'Westphalian', statal model of sovereignty itself. It will address the ways in which the new sub-state nationalist agenda constitutes one level of a tripartite series of issues emerging across supra-state, sectoral, and sub-state levels. Any meaningful analysis of the questions posed by substate national societies to plurinational States must be contextualized within the framework of broader global challenges to all nation-States. Various

European Union, is far from over. N Walker 'Late Sovereignty in the European Union' European Forum Discussion Paper (EUI Florence Robert Schuman Centre 2001). This term is a more accurate description of our age than the often-used and over-stated mantra: 'post-sovereignty'.

7 M Keating Nations Against the State-The New Politics of Nationalism in Quebec, Catalonia and Scotland (2nd edn Palgrave London 2001) 275.

8 This process of 'externalization' takes place whether the aim is statehood, as in the Scottish National Party's 'independence in Europe' strategy (M Happold 'Independence in or out of Europe? An Independent Scotland and the European Union' (2000) 49 ICLQ 15-34) or increased autonomy within the State which will also involve enhanced powers of 'paradiplomacy', as is to be found in the mainstream Catalan nationalism of the Convergencia $i$ Unio: 'Catalonians rattle Madrid with bid for sovereign power' E Nash The Independent 26 Mar 2003.

9 P Heywood 'Spanish regionalism, a Case Study' Working Documents in the Study of European Governance, No 2 (CSEG Nottingham 2000) at 12; TA Börzel 'From competitive regionalism to co-operative federalism: the Europeanization of the Spanish state of the autonomies' (2000) 30 Publius 17-142 at 21; TC Salmon 'Oxymorons: The Scottish Parliament, the European Union and International Relations?' in TC Salmon and M Keating (eds) The Dynamics of Decentralization: Canadian Federalism and British Devolution (McGill/Queens University Press Montreal/London 2001) 63-84; L Harel 'The International Relations of the National Assembly of Quebec' (2003) 26 Canadian Parliamentary Review 4-7.

10 D Latouche "'Quebec, See Canada": Quebec Nationalism in the New Global Age' in A-G Gagnon (ed) Quebec: State and Society (2nd edn Nelson Canada Scarborough 1993); F Requejo 'La acomodación 'federal' de la plurinacionalidad. Democracia liberal y federalismo plural en España', in E Fossas and F Requejo (eds) Asimetría federal y estado plurinacional. El debate sobre la acomodación de la diversidad en Canadá, Bélgica y España (Trotta Madrid 1999) 303-44. F Requejo 'Political Liberalism in Multinational States: the legitimacy of plural and asymmetrical federalism' in A Gagnon, C Taylor, and J Tully (eds) Multinational Democracies (CUP Cambridge 2001) 110-32 at 127. 
matters are at stake here for traditional concepts of statehood, for example: the hierarchy of competing levels of legal authority at supra-state, sub-state, and sectoral levels; the normative resilience of State constitutions in the face of these competing authority sites; and the continuing reliability, as explanatory devices, of traditional models of statehood and of their fundamental doctrinal components, such as sovereignty and territorial integrity. It is therefore the central aim of the article to situate the contemporary nationalist challenge within this wider condition of global political and constitutional flux and within wider-ranging contemporary debates, particularly in Europe but also in North America, concerning the nature of statehood itself.

Flowing from this analysis, in Section III it will be observed how the challenge of sub-state nationalism manifests itself increasingly in demands for improved accommodation within the State rather than in the threat of secession. The article will conclude by suggesting that, although internal accommodation constitutes a seemingly less radical challenge to the State than does 'separatism', ${ }^{11}$ in fact the new debates emerging around the nature of the State and its plurinational nature perhaps raise more difficult questions for established conceptions of constitutional sovereignty than does secession.

\section{SITUATING NATIONALISM IN AN AGE OF 'GLOBALIZATION'}

There are a number of contemporary politico-legal challenges which presently exert themselves upon States, and which together call into question the very viability of the nation-State, at least in so far as the State is conceptualized to represent a 'Westphalian' model of absolute sovereignty. ${ }^{12}$ These 'challenges' are in fact rival sites of authority which in our time contest constructions of the nation-State as the pre-eminent, or according to certain positivists, the exclusive, site of territorial sovereignty; and which, in doing so, also offer alternative reference points for both the identity and the loyalty of the citizen. These rival sites of authority can be categorized in terms of 'levels', of which, a number of commentators agree, there are three. First, and in Europe at least the most topical, is the emergence of supra-state political and legal orders - most prominently the European Union. Although operating at the supra-state level, entities such as the EU remain territorial in their remit. For example, the EU has been described as a 'post-State' polity in that it operates above the State but remains a fully territory-based polity. ${ }^{13}$ Certainly the EU is unique in

11 A central contention of the article is that sub-state nationalism and separatism are not synonyms.

12 It should be noted from the beginning that any presentation of the Peace of Westphalia of 1648 as the defining moment in the birth of the modern nation-State is of course simplistic and largely inaccurate, but insofar as the term 'Westphalia' has passed into common juridical parlance to encapsulate untrammelled State power, it continues to serve as a useful caricature. 347.

3 N Walker 'The Idea of Constitutional Pluralism' (2002) 65 Modern Law Review 317-59 at 
terms of the sophistication of its institutional infrastructure, and other entities such as the North American Free Trade Agreement could certainly not be described as 'post-State'; however, even in the context of NAFTA, certain comparable issues concerning the transference of State sovereignty have arisen. ${ }^{14}$

Secondly, at a 'sectoral' level, ${ }^{15}$ there exists a primarily economic challenge to State sovereignty through the extra-territorial dynamic of what is often loosely termed 'globalization', ${ }^{16}$ but which also embraces a networked and powerful system embracing political and legal dimensions. ${ }^{17}$ This process, although consisting primarily of an economic imperative, can impact on legal authority through regulatory devices (eg in the practices of the World Trade Organization), ${ }^{18}$ and becomes in many respects politically, if not strictly legally, authoritative. In a sense, therefore, the sectoral challenge is a functional one, affecting more the State's 'capacity' than its 'competence'. As Marks puts it, globalization 'changes the context in which state functions are exercised'. ${ }^{19}$ This can be distinguished from the suprastate challenge given that the sectoral challenge operates on a largely extraterritorial or deterritorialized basis, creating claims that it constitutes a new form of territorially intangible empire which is progressively incorporating the globe within open and expanding frontiers. ${ }^{20}$ The third challenge is that presented by sub-state nationalism. This resembles the supra-state challenge in being territorially based, but is distinctive in so much as it operates primarily within the State; although, as will be explored, sub-state societies are also capable of acting beyond the State by building networks and relationships at extra-state level.

A body of literature has built up analysing the implications of these new sites of challenge for the independent operation of municipal constitutional 21.

14 A Gagnon 'Quebec: The Emergence of a Region-State?' (2001) Scottish Affairs 14-27 at

15 M Keating Nations Against the State (n 7) 46.

${ }^{16}$ CR Beitz 'Cosmopolitan Liberalism and the States System' in C Brown (ed) Political Restructuring in Europe. Ethical Perspectives (Routledge London 1994); J Waldron 'Minority Cultures and the Cosmopolitan Alternative' in W Kymlicka (ed) The Rights of Minority Cultures (OUP Oxford 1995) 93-119; D Held et al (eds) Global Transformations (Polity Press Cambridge 1999); M Moore 'Globalization, Cosmopolitanism, and Minority Nationalism' in M Keating and $\mathrm{J}$ McGarry (eds) Minority Nationalism and the Changing International Order (OUP Oxford 2001) $44-60$.

17 J Habermas and M Pensky The Postnational Constellation: Political Essays (Polity Press Cambridge 2001) 60

$18 \mathrm{~J}$ Weiler The EU, the WTO, and the NAFTA: Towards a Common Law of International Trade? (Academy of European Law, EUI Florence/OUP Oxford 2000); DZ Cass 'The 'Constitutionalization' of International Trade Law: Judicial Norm-Generation as the Engine of Constitutional Development in International Trade' (2001) 12 EJIL 39-75 at 42; J Habermas 'The European Nation-State and the Pressures of Globalization' (1999) New Left Review 46-59 at 49.

19 S Marks The Riddle of all Constitutions: International Law, Democracy, and the Critique of Ideology (OUP Oxford 2000) 76.

20 M Hardt and A Negri Empire (Harvard University Press Cambridge MA 2000) xii (emphasis in original). 
systems. Questions are now being raised concerning the continuing capacity and competence of the State to manage, or otherwise exercise control over, social and economic relations; ${ }^{21}$ and this has led in turn both to theoretical deconstructions of established notions of statal authority (in particular, reified visions of the State as the receptacle of absolute sovereignty), ${ }^{22}$ and to radical revisions in the study of constitutions and constitutionalism itself. ${ }^{23}$ This work has concentrated largely upon either the challenges posed at supra-state level through transnational politico-legal constructs such as the European Union and the North American Free Trade Agreement, or alternatively, upon those challenges presented by economic, political, and legal forces operating at the sectoral level and facilitated to some extent by regulatory machinery such as the WTO. This article contends, however, that the role played by sub-state nationalism offers an additional radical dynamic which has generally been missing from this debate; in fact, sub-state nationalism poses similar questions about the coherence of the Westphalian model of the nation-State, and as such this phenomenon constitutes a site of authority comparable to these other two sites of challenge.

This task of explaining the role of sub-state nationalism in these great changes begins with a consideration of how this phenomenon, which may seem only to undermine the authority of the specific State within which a particular sub-state national society is located, rather than to raise more fundamental questions about the nature of statehood itself, can be located in juxtaposition to these two other forces. In other words, how sub-state nationalism takes its place as part of a triad of rival sites, linking with the suprastate and sectoral forces in posing broad, structural challenges to the very foundations of the Westphalian statal model. In suggesting this linkage between sub-state nationalism and these other sites it is important to begin by addressing the common preconception that sub-state nationalism does not in fact raise, in any meaningful way, fundamental issues concerning the nature of the nation-State. It is frequently argued first, that as a political strategy sub-state nationalism is in fact driven by, and is dependent upon, the same statal dynamics that motivate existing States; and secondly, that as a consequence, sub-state nations as territorial sites of constitutional authority are just as likely to be affected in negative ways by new supra-state and

21 D McCrone 'Neo-Nationalism in Stateless Nations' (2001) Scottish Affairs 3-13; D Held 'Farewell to the Nation-State' Marxism Today (Dec 1988) 12-17.

22 E Christodoulidis Law and Reflexive Politics (Kluwer Dordrecht 1998); N MacCormick Questioning Sovereignty: Law, State and Nation in the European Commonwealth (OUP Oxford 1999); J Weiler The Constitution of Europe: 'Do the new clothes have an emperor?' and other essays on European integration (CUP Cambridge 1999).

${ }^{23} \mathrm{KH}$ Ladeur 'Towards a Legal Theory of Supranationality: The Viability of the Network Concept' (1997) 3 European Law Journal 33-54; J Tully Strange Multiplicity: Constitutionalism in an Age of Diversity (CUP Cambridge 1995); DM Curtin Postnational Democracy (Universiteit Utrecht 1997); and D Chalmers 'Postnationalism and the Quest for Constitutional Substitutes' 27 (2000) Journal of Law and Society 178-217. 
sectoral sites of authority as are nation-States themselves. It will be argued that this argument, while correctly identifying ways in which statal and substatal polities are each affected by globalizing dynamics, goes too far in this process of elision, thereby overlooking or under-emphasizing important points of demarcation between the effects of globalization on these differing models of polity.

The starting point in engaging with this argument is to observe the historical relationship between State nationalism and the construction of the nation-State, whereby nationalism as an instrumental political device of the modern age performed a central task in the state-building project by providing the ideological glue adhering the loyalty of the populace to the physical space of the State. ${ }^{24}$ In this sense, through the process of State-building, ${ }^{25}$ nationalism in the 19th and 20th centuries became the key political device which tied together, in a synergetic relationship, the populace, the territory and the constitutional order of the evolving State. And, for the purposes of this account, it should be recalled also that constitutionalism was central to this process. ${ }^{26}$ A comparable process can also be said to have occurred among sub-state nations, with similar dynamics of nation-building at work. $^{27}$ This is particularly true of those sub-state nations, such as Scotland, which entered the modern era as independent States, but it is also the case in more subtle ways for sub-state nations such as Catalonia and Quebec, which although never independent, did find the constitutional space to build politically and culturally discrete societies, particularly from the 19th century onwards.

Therefore, at first glance it appears that the political agenda of sub-state nationalism should not in fact challenge deeper conceptions of statehood; on the contrary, given that the Westphalian State is, according to the constructivist model of Gellner and others, bound symbiotically to the ideology of nationalism, it is widely understood that the principal, if not exclusive, political strategy of sub-state nationalist movements is simply to join the club of

24 E Gellner Thought and Change (Weidenfeld \& Nicholson London 1964) 169; K Deutsch Nationalism and Social Communication: An Enquiry into the Foundations of Nationality (MIT Press Cambridge 1966); EJ Hobsbawm Nations and Nationalism since 1780: Programme, Myth, Reality (CUP Cambridge 1990); B Anderson Imagined Communities: Reflections on the Origin and Spread of Nationalism (Verso London 1991); M Weber General Economic History (Collier Books New York 1966); J Breuilly Nationalism and the State (2nd edn MUP Manchester 1993).

25 E Gellner Nations and Nationalism (Blackwell Oxford 1983); W Reinhard (ed) Power Elites and State Building (Clarendon Press Oxford 1996); H Rae State Identities and the Homogenisation of Peoples (CUP Cambridge 2002).

26 S Holmes Passions and Constraints: On the Theory of Liberal Democracy (Chicago IL Chicago University Press 1995) xi; JR Resina 'Post-national Spain? Post-Spanish Spain?' 8 Nations and Nationalism (2002) 377-96 at 381.

27 D McCrone The Sociology of Nationalism: Tomorrow's Ancestors (Routledge London 1998) 11; AD Smith Nationalism and Modernism: A Critical Survey of Recent Theories of Nations and Nationalism (Routledge London/New York 1998) 11-16. 
nation-States as presently ordered. ${ }^{28}$ It follows, therefore, that sub-state nationalism is often considered to be an outmoded political strategy which seeks to secure a seat at the Westphalian table for sub-state national societies at a time when that table is itself being over-turned or at least re-ordered. The dismissal of sub-state nationalism (and indeed of State nationalism) as outmoded political strategies is nicely captured in Hobsbawm's famous account: 'the phenomenon [nationalism] is past its peak. The owl of Minerva which brings wisdom, said Hegel, flies out at dusk. It is a good sign that it is now circling round nations and nationalism.' 29 According to this account, rather than challenging traditional conceptions of statehood, sub-state nationalism in fact depends upon their survival and is accordingly as much threatened by the supra-state and sectoral rivals to the nation-State model as is the State itself. The death-knell of nationalism, sounded so loudly across the political spectrum in the modern age, and given new force by the political, economic, and technological transformations in our time, rings as loudly, by way of these constructions, for the myopia of luddite minority nations, harking sentimentally after a bygone age, as it does for the conceit of the nationState clinging doggedly to the last vestiges of its own imagined constitutional and political autarchy. And for good measure the dismissal of sub-state nationalism as a practical irrelevance is often accompanied by a normative critique of the phenomenon on the grounds that it is atavistic, reactionary, and antihistorical. ${ }^{30}$

It is submitted that this construction of sub-state nationalist movements misses certain important factors which do in fact work to link sub-state nationalism to the other sites of authority that rival the State, and together these three forces, albeit in differing ways, constitute a common challenge to the political capacity, and at times also to the legal competence, of the State. Furthermore, this linkage with globalizing forces highlights that the reasons behind the reemergence of sub-state nationalism at a time when the concept of the nationState is being called into question, are in fact highly complex; and as such, it is simplistic to caricature this phenomenon as a last desperate attempt to leap aboard the sinking ship of statehood, just as this vessel disappears beneath the waves of globalization. Taking this point further, it is possible to turn to three arguments which challenge the stereotypical representation of the constitutional aspirations of sub-state nationalist movements as fatally misguided.

First, it can be argued that the nation-State never was, as statist constructions have assumed, the possessor of untrammelled sovereignty. The narrow positivist construction of sovereignty as the embodiment of absolute legal power seems to miss the relational dimension of sovereignty which has always

28 JM MacPherson Is Blood Thicker Than Water?: Crises of Nationalism in the Modern World (Vintage Books Toronto 1998).

29 Hobsbawm (n 24) 192.

30 M Ignatieff The Warrior's Honor: Ethnic War and the Modern Conscience (Metropolitan Books New York 1998); MacPherson (n 28) 25-6. 
linked the political and the legal. These aspects have combined in the constitution of sovereignty as (per Loughlin) a thing 'socially constructed' ${ }^{31}$ In terms of this more nuanced politico-legal formulation, we might say that sovereignty has served, and continues to serve, as a relative as well as a relational concept; its viability dependent upon the strength of the differing factors impacting upon, and limiting the freedom of, the central governmental organs of the State. Therefore, in this sense the classical Westphalian formulation of the State as a legally autonomous unit was always an exercise in hyperbolic self-aggrandisement by States that failed to reflect the reality of international interdependence and the relative strengths and weaknesses of different States at different times. ${ }^{32}$ Furthermore, the forces which have served to limit the freedom to manoeuvre of particular States, and in doing so to restrict their sovereign sphere of operations in both de facto and at times de jure senses, have not been exclusively external. Sub-state forces, including sub-state national societies within plurinational states, have in certain cases been able to negotiate degrees of autonomy within the State. The existence of federal states is an obvious example of this process; but even in unitary States it has been possible for sub-state national societies to secure levels of autonomy, even though in unitary States, such as the UK and Spain, these measures of self-rule may not have been formally entrenched in the State's constitution. For example, Paterson has argued that, even before the devolution settlement embodied in the Scotland Act 1998, Scotland through 'administrative independence' enjoyed a level of autonomy comparable to other small European nations which, despite formal independent statehood, have always had to negotiate their autonomy in relation to big powers. ${ }^{33}$ Also in Spain, while the Constitution of 1978 does provide for the autonomy of what have come to be known as the autonomous communities, the devolution of powers itself has operated upon an ad hoc basis through the bilateral negotiation of statutes of autonomy with the central State, a process which has been heavily contingent upon the political muscle of the sub-state territory in question. ${ }^{34}$ So successful have Catalonia and other sub-state territories been in establishing strong models of autonomy through this semi-formal and largely unentrenched system, that it is now widely argued that Spain, while still in formal terms a unitary State, is now in reality 'quasi-federal'. 35

31 Loughlin The Idea of Public Law (n 4) 73.

32 SD Krasner Sovereignty: Organized Hypocrisy (OUP Oxford 1999).

33 L Paterson Autonomy of Modern Scotland (Edinburgh University Press 1994). See also JDB Mitchell Constitutional Law (2nd edn Green Edinburgh 1968) 209, and Walker who notes how historically Scotland has been able to use the unitary State to its advantage. N Walker 'Constitutionalism in a New Key' in G De Burca and J Scott (eds) The EU and the WTO: Legal and Constitutional Aspects (Hart Publishing Oxford 2001) 112.

34 E Fossas ‘Asymmetry and Plurinationality in Spain', Working Paper 167 Institut de Ciències Politiques i Socials (Universitat Autònoma de Barcelona 1999) 6; and Heywood 'Spanish regionalism, a Case Study' (n 9) 6.

35 L Moreno The Federalization of Spain (Frank Cass London 2001) 31; P Heywood The Government and Politics of Spain (MacMillan London 1995) 162; JM Colomer 'The Spanish 
Another related development has been the way in which sub-state national societies, armed with a sense of their own 'nationhood', have also asserted an international presence through the phenomenon which now enjoys the classification of 'paradiplomacy' ${ }^{36}$ In both these ways, sub-state national societies have developed spheres of operation which transcend traditional statal imaginings about political, and perhaps even legal, sovereignty; they have in certain cases been successful in negotiating power both within the supposedly monolithic construction of the sovereign State, and even within the 'billiard ball' world of international law and relations. In fact it is in many respects international law rather than the constitutional order of their own States which has held back radical approaches to shared sovereignty within particular multinational States. The mythical notion of absolute sovereignty in the municipal sphere is in no small measure a construction of international legal theory which traditionally envisaged personality as a unitary concept and treated the central organs of government within a State as internally sovereign and indivisible. This may have helped bolster monistic conceptualizations of internal sovereignty in a formalistic legal sense even when in de facto terms internal sovereignty had long since been compromised and qualified. For example, a State cannot use federalism or other forms of internally 'divided sovereignty' as an excuse for its failure to comply with international obligations. In the context of the case studies addressed here, this has had serious knock-on effects for sub-state autonomy in those States which are members of strong international legal regimes, in particular the European Union or the Canada-US Free Trade Agreement of 1987. ${ }^{37}$

The efforts made by sub-state nations to develop an international presence may suggest therefore, that as the constitutional authority of States weakens further both in terms of capacity and of formal competence ${ }^{38}$ against the backdrop of the contemporary dynamics of the global economic and political environment, sub-state national societies may be well placed to exploit such developments further in order to find governmental space at both the reconstituted State level and at the developing 'extra-state' or 'post-state' levels, provided these opportunities are made available beyond the State. For exam-

"state of the autonomies": non-institutional federalism' in P Heywood (ed) Politics and Policy in Democratic Spain (Frank Cass London 1999) 40-52; T A Börzel States and Regions in the European Union. Institutional Adaptation in Germany and Spain (CUP Cambridge 2002).

36 H Michelmann and P Soldatos (eds) Federalism and International Relations: The Role of Sub-units (Clarendon Press Oxford 1990); F Aldecoa and M Keating (eds) Paradiplomacy in Action (Frank Cass London 1999); D Laitin 'National Identities in the Emerging European State' in M Keating and J McGarry (eds) Minority Nationalism and the Changing International Order (OUP Oxford 2001) 84-113; J Mitchell and M Cavanagh 'Context and Contingency: Constitutional Nationalists and Europe' in M Keating and J McGarry (eds) op cit 246-63.

37 PM Leslie 'Asymmetry: Rejected, Conceded, Imposed' in F Leslie Seidle (ed) Seeking $a$ New Canadian Partnership: Asymmetrical and Confederal Options (Institute for Research on Public Policy Montreal 1994) 37-69 at 40.

38 Supra-state organizations such as the EU certainly challenge the constitutional competence as well as the capacity of Member States-Case 6/64, Costa v ENEL [1964] ECR 1141. 
ple, proto-institutions at supra-state level, such as the Committee of the Regions within the EU, are already offering pathways, albeit rather weak ones, for these territories to develop an extra-state presence. ${ }^{39}$

Secondly, although it seems incontestable that contemporary challenges presented at supra-national and sectoral levels do indeed constitute sites of authority which rival that of the nation-State, it is also necessary not to overstate this point, bearing in mind that the State remains in many respects very resilient. ${ }^{40}$ Even in the age of 'late sovereignty', a sense of balance should be maintained, as McCrone reminds us: 'It is too facile to claim that, in a globalised world, the age of the state is dead, although it is also now much harder to sustain the argument that the state is all-powerful. ${ }^{41}$ The State continues to perform important economic and political functions: a fact recognized by substate nationalist movements anxious to protect and foster their particular societies. Perhaps the main reason for the State's resilience is its control of territory and the continuing normative authority which comes with territorial jurisdiction. ${ }^{42}$ There is a strong functional dimension to territorial control. As Gagnon notes, territory, 'remains one of the rare areas within liberal democracies where it is still possible to maintain representation and to demand political accountability from political actors. ${ }^{43}$ In this sense it can be argued that the resilience of the State also has a normative dimension. For example, it may be that a rule-bound international society can itself only be built upon nationstates which themselves respect the rule of law; ${ }^{44}$ and that it is only within identifiable territorial units of a manageable size that people can realistically form ties of identity and loyalty through which they can take part meaningfully in the democratic process.

Many sub-state nationalist movements are aware of those aspects of statehood which continue to offer the prospect of institutional defences against globalising tendencies; indeed, it is largely from recognition of the State's enduring potential that nationalism retains its potent political force today. Since the State retains important strengths, either greater autonomy within a strong State or even secession are attractive options for a sub-state national society. The latter option of course promises statehood itself, while the former

\footnotetext{
39 F Aldecoa and M Keating 'Introduction' in F Aldecoa and M Keating (eds) Paradiplomacy in Action. The Foreign Relations of Subnational Governments (Frank Cass London 1999) 1-16 at 7.

40 Loughlin The Idea of Public Law (n 4) 94-5. See also Loughlin Sword and Scales (Hart Publishing Oxford 1999) 145; R Brubaker Nationalism Reframed: Nationhood and the National Question in the New Europe (CUP Cambridge 1996); and M Mann 'Nation-states in Europe and other continents: diversifying, developing, not dying' (1993) 122 Daedalus 115-40 at 118.

41 D McCrone 'Neo-Nationalism in Stateless Nations' (n 21) 11.

42 Once again international law remains a powerful force in the defence of State power. For example, out of respect for the principle of territorial integrity, the international community refuses to recognize Kosovo as an independent State even though it is in any meaningful sense a politico-territorial unit entirely separate from the influence of Serbia-Montenegro.

43 A Gagnon 'Quebec: The Emergence of a Region-State?' (n 14) 24.

44 P Hirst and G Thompson Globalization in Question (Polity Cambridge 1996) 190-4.
} 
allows the sub-state national society to govern itself within a host State which is itself a sufficiently robust environment to protect to some extent the autonomy regime from forces external to the State.

The third argument challenging stereotypical presentations of the constitutional aspirations of sub-state nationalist movements is the way in which these movements are both aware of, and prepared to harness for their own purposes, the changing role of the nation-State. In this sense, the challenge presented by sub-state national societies to the nation-State does not portend a loss of power from the State (as does the challenge at the sectoral level), but rather the redistribution of power within it. From this observation it follows that the sub-state challenge is comparable to the supra-state challenge in that both represent the relocation of State power to alternative territorial sites; by contrast the sectoral challenge represents the diffusion of power to deterritorialized sites. It seems that the new supra-national and sectoral sites of authority which are challenging certain traditional statal roles are not necessarily considered by sub-state nationalists to constitute a threat to their aspirations for constitutional autonomy in the same ways and to the same extent that they are often perceived by State elites to present a danger to State authority. In fact, Keating and others contend that sub-state nationalist movements are developing highly imaginative strategies and progressive political agendas in the face of these globalizing forces; and that, given the ways in which these sub-state movements envisage radical reconfigurations in the State polity, these strategies and agendas require a rethinking of traditional constitutional doctrine. ${ }^{45}$

Although it is important not to overlook the fact that strains of 'statist' secessionism remain strong within nationalist discourse in Catalonia, Quebec, and Scotland, in recent constitutional debates it seems that more powerful nationalist forces within these sub-state national societies are increasingly aware of the changing global context within which their political demands require to be articulated, and that this growing realization is resulting in debates which are far more sophisticated than might have been anticipated by those who consider sub-state nationalist movements to be monolithic in positioning their societies as 'proto-States in waiting'. For example, the European strategy of the notionally independentist Scottish National Party is notable in this context, as is the 'Barcelona Declaration' of 1998 in which nationalist parties in the Basque Country, Catalonia, and Galicia called for a reconfiguration of the Spanish State along plurinational lines and emphasized the increasing orientation of these parties towards the EU. In a related way, during the Quebec referendum

45 M Keating 'Managing the Multinational State: Constitutional Settlement in the United Kingdom' in TC Salmon and M Keating (eds) The Dynamics of Decentralisation (n 9) 21-45 at 23; D McCrone The Sociology of Nationalism (n 27) 182; D Saleé 'La Mondialisation et la construction de l'identité au Québec' in M Elbaz, A Fortin, and G Laforest (eds) Les Frontiéres de l'identité: Modernité et postmodernisme au Quebéc (Les Presses de l'Université de Laval Sainte-Foy 1996). 
campaign in 1995, the Quebec nationalist parties balanced their campaign for sovereignty by emphasizing Quebec's commitment to NAFTA. ${ }^{46}$

A related argument suggests that in some ways sub-state national societies are perhaps better prepared than the State to face these changing realities, because, with a long tradition of advancing strategies for constitutional change, nationalist movements within these territories are already acclimatised to the process of challenging and re-thinking fundamental questions of constitutional authority. It may be, therefore, that these societies are less prone to fetishize existing institutions and authority structures than are existing States instilled with a conviction of constitutional absolutism. For example, these territories have been quick to seize upon the opportunities to engage diplomatically beyond the State. These engagements can be formal (one example mentioned above is the Committee of the Regions of the EU), or more informal and bilateral ties, as exemplified by the forging of cross-cultural links and economic ties between sub-state nations and regions in Europe; for example, Catalonia has begun to work through these less formal networks as one of the 'Four Motors of Europe', linking with Baden-Württemberg, Lombardy, and Rhône-Alpes to promote itself as an advanced rather than a struggling economy.

At the same time, however, these processes of engaging beyond the State should not be seen as a sign that territorial attachments are no longer important. Instead the sub-state nation continues to provide some stability in an age of transformation. As Keating puts it: 'these identities ... provide a reference point for politics in a confusing world, in which the old concurrent spheres of state, nation and policy making systems no longer coincide'. ${ }^{47}$ Inherent in this process then is a deep ambivalence which is also present among dominant or statal national societies themselves as they at once seek to take advantage of the opportunities of globalization, but remain closely attached to their own societies. In this context McCrone suggests that the national unit offers a form of psychological security for the citizen trying to come to terms with an increasingly complex world: 'Nationalist movements can encapsulate cultural defence, the pursuit of political resources, as well as being vehicles for social identity in times of rapid social change. ... ' In short, the sub-state nation, in a way similar to the dominant national society, provides both security and opportunity: 'it provides a sense of historical continuity coupled with strategies for addressing the future.' 48

Furthermore, sub-state nationalist movements are often forced by the logic of their own arguments to recognize that shifting patterns of statal authority also impact upon their own sub-state societies. For example, one nationalist

\footnotetext{
46 See respectively: SNP Election Manifesto, Apr 2003; Declaració de Barcelona (Convergencia i Unio Barcelona 1998) 1; RA Young The Struggle for Quebec: From Referendum to Referendum? (McGill-Queen's University Press Montreal/London 1999) 14.

47 M Keating Nations Against the State (n 7) 264.

48 D McCrone 'Neo-Nationalism in Stateless Nations' (n 21) 11.
} 
strategy is to argue that external forces such as the EU, in restricting the existing governmental functions exercised by the host State within which the substate territory is located, make the State less important in governmental terms to the sub-state nation (hence 'independence in Europe' type arguments). Having recruited the influence of external forces to strengthen its argument that the relevance of the host State is in decline, and in drawing succour from the potential avenues offered to the sub-state national society by alternative normative and strategic sites of authority, it would be disingenuous, and indeed unsustainable, for the nationalist movement not to acknowledge that the pressures which undermine State power will also, albeit in different ways, undermine the scope for action of new, smaller nation-States or increasingly autonomous units within larger States; even if sub-state nationalists will still maintain that such smaller units are better able to cope with, and respond to, these external pressures. Therefore, these groups will need to formulate constitutional agendas which, in light of these changes, must be meaningfully contextualized if they are to meet with any possibility of implementation. For example, realpolitik applies in any claim to 'sovereignty': 'sovereignty consists of a plausible claim to ultimate authority made on behalf of a particular polity. ${ }^{49}$ This reality serves to condition autonomy claims, rendering terms like 'independence' and 'separation' increasingly redundant; a point that will be developed in Section III.

Thus far an attempt has been made to introduce the sub-state national challenge to plurinational States in the context of wider forces which today operate to constrict the existing politico-constitutional capacity and competence of the nation-State. It has been argued that in one sense the classical Westphalian formulation of the State as a politically self-contained and legally autonomous unit was always a caricature that failed to reflect international interdependence and the relative strengths and weaknesses of different States at different times,${ }^{50}$ and that this characterization also served to underestimate the existing role of sub-state territories in limiting central State authority. It has also been suggested however, that this is not the whole story, and that this historical reality requires to be tempered by an appreciation that in many other ways the power of the nation-State endures in important respects. It is therefore within this complex environment of wider global change set against the endurance of State power, that the constitutional agendas of sub-state national societies require to be re-formulated. On the one hand, insofar as the State does retain power in the contemporary world, an increasingly autonomous sub-state nation can use this comfort-zone to extend its territorial authority within the State by drawing upon those strategies which it has always used to negotiate governmental space within the State (and indeed beyond it, through

\footnotetext{
49 Walker 'The Idea of Constitutional Pluralism' (n 13) 345 (emphasis in original).

50 G Simpson Great Powers and Outlaw States: Unequal Sovereigns in the International Legal Order (CUP Cambridge 2004).
} 
paradiplomacy); and on the other hand, sub-state national societies must also attempt to find new opportunities even in the face of those contemporary processes of both deterritorialization (the sectoral challenge) and reterritorialization (the supra-state challenge) which do, despite the continuing viability of the nation-state, in many ways both supplant the governmental capacity, and compromise the competence, of the nation-state model in novel and deeply penetrative ways. Thus, sub-state national societies are perhaps in a useful position to produce imaginative governmental strategies, given the predisposition towards constitutional change which has long informed their political praxis, and given the practical opportunities which increasingly fluid normative sites now seem to offer to flexible political operators.

Having introduced and attempted to contextualize the sub-state national society challenge to plurinational States in this way, the article will now address in more detail the ways in which sub-State national societies themselves represent a rival site of authority which works to bring about a reconception of the plurinational nation-state, in particular by the ways in which they challenge traditional constructions of the State's constitutional selfunderstanding. In this sense it will be suggested that the constitutional aspirations of sub-state national societies such as Catalonia, Quebec, and Scotland are more nuanced than is often thought; and that the models of institutional change now being advocated within these territories focus increasingly upon reconfiguring relations with their respective host states in preference to secession and full statehood.

\section{ESCHEWING SECESSION: SUB-STATE NATIONAL SOCIETIES IN A COMPLEX WORLD}

Insofar as the sub-state national society challenge to the constitutional authority of particular States links with supra-state and sectoral forces in contesting established certainties concerning the nation-State, it does so at the most fundamental level by challenging traditional monistic conceptions of internal constitutional sovereignty with radically reconfigured models of authority. ${ }^{51}$ Forces operating at supra-state and sectoral levels clearly challenge the ways in which State sovereignty can manifest itself externally. But in penetrating deep into the legislative and executive roles of the domestic branches of government, they also compromise the reality of the State's municipal sovereignty; in other words, they constrict the capacity and at times even the competence of the State constitution to act as the ultimate repository of governmental power which supposedly allocates and coordinates in totality

51 The use of the term 'monistic' here denotes a unitary construction of the internal sovereignty of the State, centred around a singular conception of the demos; it is not used in the technical legal sense to describe the domestic legal order's external relationship to international law. 
the division of public legal functions operating within the State's territory. Elaborating further upon this dynamic, the vision of 'the encompassing constitution' is now called into question both in explanatory terms for its continuing capacity to describe in an authentic way recent and ongoing transformations in the relations of power between the State and external forces; and, in prescriptive terms, for its suitability to meet the changing demands made by citizens which stem from these transforming relations of power. For example, Catalan nationalists argue that the formal description of Catalonia as merely an autonomous community within Spain fails to take account of its unique 'national' status (a conviction shared in the Basque Country and Galicia); similarly Quebec nationalists refute the monistic national assumptions which underpin symmetrical federalism in Canada. Interestingly, by contrast, the highly diverse models of devolution in the United Kingdom are considerably more sensitive to the historical and societal differences which demarcate Scotland, Wales, and Northern Ireland both from England and from one another.

It is in the dual context of transforming relations of power and concomitant alterations in the expectations of citizens that the sub-state national society challenge must be cast. It has been noted in passing that the sub-state challenge to the sovereign authority of the State and its constitutional apparatus can manifest itself in two differing aspirations: first, the desire to withdraw from the State, or second, the intention to reconstitute intra-state relations through some measure of accommodation short of secession. These aspirations will now be discussed further in order to draw out the implications they might hold for constitutional sovereignty. The former aspiration, secession, is the spectre which sub-state nationalism is so often deemed to represent, and at first sight it seems the more threatening of these two challenges to the State's authority, in particular to its notion of constitutional sovereignty. The second and apparently less radical challenge is posed today by sub-state national society demands for increased autonomy and representation within, and better recognition by, the State. It is becoming ever more the case that both the political strategy of nationalist groups within sub-state national societies and the reality of ongoing processes of institutional accommodation within plurinational States, tend towards the latter process (internal accommodation) through the pursuit of complex and case-specific models for the reconstitution of sub-state-host State relations.

Therefore, while strong separatist movements do exist, nationalist opinion within plurinational States is veering increasingly towards enhanced autonomy and representation within, and better recognition by, the State, in preference to full-blooded secessionism. There seem to be several reasons for this. First, it has been observed that in the modern world, the larger State, insofar as it retains power, might act as a bulwark against external forces which would otherwise undermine sub-state autonomy just as they weaken the State's power. The attractions of such an arrangement have taken hold particularly within Catalan nationalism where the dominant strategy is to develop a 
stronger role in Europe in conjunction with strong ties to the rest of Spain. ${ }^{52}$ Therefore, even when a sub-state national society advances a strategy which appears to be secessionist, the constitutional outcome it in fact seeks is often a heavily compromised version of statehood which bears little resemblance to the traditional Westphalian model. For example, the three main Quebec nationalist parties in advance of the Quebec referendum on 'sovereignty' in 1995 made a pact whereby, in the event of a victory for the nationalist side, they would seek to negotiate an economic and political partnership with the rest of Canada. As Robert Young observes, this was a notion of sovereignty with a strong insurance policy stemming from continued close association with Canada: 'sovereignty would bring gains on several fronts while the partnership would protect voters from short-term economic losses and eventual isolation from Canada.' ${ }^{53}$ With this partnership model Quebec nationalists proposed that Quebec would keep the Canadian currency, maintain free trade between Canada and a 'sovereign' Quebec through joint institutions, and create the option of joint Quebec-Canada citizenship for its residents. ${ }^{54}$ Quebec is but one example; nationalists in Catalonia and Scotland have also developed nuanced approaches to 'independence', in the hope that the substate society can negotiate considerable influence within supra-state bodies without seceding from the host State; ${ }^{55}$ and in this respect the line between the aspiration for statehood and that for autonomy can itself become blurred. ${ }^{56}$

Another reason why solutions short of full secession are preferred is that there are often strong identity and loyalty ties between the sub-state national society and the host State; sub-state national societies such as Catalonia, Quebec, and Scotland see Spain, Canada, and the UK respectively, as a product of a union or compact between or among nations. ${ }^{57}$ Certainly resentment

52 K McRoberts Catalonia: Nation Building without a State (OUP Toronto 2001) 68. On the general realignment of sub-state nationalism in the context of Europe, see C Jeffrey 'Sub-National Mobilization and European Integration' 38 (2000) Journal of Common Market Studies (2000) $1-24$.

53 RA Young The Struggle for Quebec: From Referendum to Referendum? (n 46) 24.

$54 \mathrm{R}$ Simeon 'Recent Trends in Federalism and Intergovernmental Relations in Canada: Lessons for the United Kingdom?' in TC Salmon and M Keating (eds) The Dynamics of Decentralization (n 9) 51; M Seymour 'Quebec and Canada at the crossroads: a nation within a nation' 6 (2000) Nations and Nationalism 227-56 at 245-7 and WJ Newman The Quebec Secession Reference: The Rule of Law and the Position of the Attorney General of Canada (York University Press Canada 1999) 12.

55 The term 'nationalist' is used in a broad sense here to include non-secessionist nationalist parties such as the Scottish Labour Party; the Scottish Liberal Democrats and the Convergencia $i$ Unio in Catalonia.

56 Although the success of these ventures by Catalonia, Quebec, and Scotland have hitherto been very mixed. A Balcells Catalan Nationalism: Past and Present (MacMillan London 1995) 197.

57 S Rokkan and D Urwin 'Introduction: Centres and Peripheries in Western Europe' in S Rokkan and D Urwin (eds) The Politics of Territorial Identity: Studies in European Regionalism (Sage London 1982) 1-17 at 11; M O'Neill 'Great Britain' (2000) 53 Parliamentary Affairs 69-95; P Romney Getting it Wrong: How Canadians Forgot Their Past and Imperilled Confederation (Toronto University Press 1999); JR Resina 'Post-national Spain? Post-Spanish Spain?' 8 (2002) Nations and Nationalism 377-96. 
may arise from a sense within the sub-state national society that the identity of the State has been appropriated by a dominant society within it. But despite this, the State can remain a constitutional construct which the sub-state national society, as a founding partner, feels a deep bond with and a vested interest in. The lingering attachment which members of sub-state national societies often show to the State can surprise political elites. Indeed, it was evidence of such attachments to the Canadian State, derived from extensive consultation with ordinary Quebecers as to their preferred constitutional options in 1995, which led Quebec nationalists to formulate a pact on economic and political partnership with Canada, and in doing so to waterdown what had been a much more 'statist' plan for Quebec 'sovereignty'. The results of this consultation process which indicated that attachments to Canada remained strong even among Quebec nationalists, were borne out in opinion polls conducted after the 1995 referendum which have shown that support for 'sovereignty' for Quebec increases when the prospect of partnership with Canada is certain, with one poll suggesting that only 30 per cent would support sovereignty if there were to be no prospect of such a partnership. ${ }^{58}$

Therefore, the complexity in the constitutional models which are now advocated by sub-state nationalists, encompassing as they do radical autonomy combined with continued relations with the State and supra-state bodies, mirrors the deeply complex patterns of identity to be found among members of sub-state national societies in relation to the various 'sites of identity' which attract their loyalty. Recent research highlights identity trends within plurinational States which are to some degree fluid, with complex matrices of shared and multi-layered identities appearing in the data. This level of complexity and fluidity in patterns of identity formation and change provides another link between the sub-state national challenge and the other alternative authority sites which have been mentioned; in particular, it links sub-state nationalism to the supra-state challenge, where observers of, for example, the EU have also identified a relationship between weakening State power and changing identity patterns. ${ }^{59}$ From this it has been argued that national identity is in fact used strategically by citizens for political purposes, and can shift according to the respective political advantages which might be derived from the variegated application of identities in differing political environments. As David McCrone, a sociologist who has carried out extensive empirical research in the area of national identity within plurinational States, argues:

there is something quite calculative about national identity which shifts according to political circumstances. It is far less a matter of sentiment than it is of political practice ... the issue, in other words, is not which one you are, but which you choose according to circumstance and purpose. ${ }^{60}$

58 Young (n 46) 41.

$59 \mathrm{R}$ Bond and M Rosie 'National Identities in Post-Devolution Scotland' Institute of Governance paper (Institute of Governance, University of Edinburgh 2002); D McCrone and L Paterson 'The Conundrum of Scottish Independence' (2002) Scottish Affairs 35-56.

${ }^{60}$ McCrone 'Neo-Nationalism in Stateless Nations' (n 21) 9. 
An example of this is the different voting patterns which occur in Catalonia in general elections as opposed to elections to the Generalitat; a phenomenon which suggests that voters use their identities in different, and often opportunistic, ways. ${ }^{61}$ This has led Moreno to comment:

At the beginning of the twenty-first century, I think we ought to reconsider both the premises and implications of all-embracing identities, for they are increasingly untenable. While being corroded by the forces of globalization, these identities are also subject to fragmentation, competition, and overlap with numerous other senses of belonging. ${ }^{62}$

In this context, the practical difficulties for any territory in becoming a new State - for example, the establishment of a currency, or the problems in joining international organizations ${ }^{63}$ - would seem to weigh heavily in any debate over the constitutional future.

A third factor for the increasing preference for accommodation within the State in place of secession is that pre-existing patterns of constitutional accommodation can themselves set new terms for the constitutional debate between sub-state national society and host State. In some sense constitutional reform brings with it what might be called 'institutional capture', whereby future debate on constitutional options is reframed through the prism of already evolving arrangements. ${ }^{64}$ For example, the recent implementation of devolution in the UK has established new terms for the nationalist debate on future developments, forcing nationalist groups not just in Scotland, but also in Wales and Northern Ireland, to re-articulate their demands for further accommodation in light of the following realities: the perceived success or failure of the new institutional arrangements in meeting sub-state demands; and the extent to which sub-state actors have been successful in managing the new autonomy regimes. For example, by the time of the Scottish parliamentary elections of 2003 it seemed that support for independence in Scotland had waned partly due to a widespread sense of disillusionment with the performance of the devolved Parliament since its inauguration in 1999. In a similar way, the debate surrounding Quebec's aspirations within Canada has been heavily influenced by the constitutional developments of the past 20 years involving the controversial patriation of the constitution from the United

61 GH De Rafael 'An empirical survey of social structure and nationalistic identification in Spain in the 1990s' (1998) 4 Nations and Nationalism 35-59, and E Roller 'The March 2000 General Election in Spain' (2001) 36 Government and Opposition 209-29 at 218.

62 L Moreno 'Ethnoterritorial concurrence in multinational societies: the Spanish comunidades autónomas' in A Gagnon, C Taylor, and J Tully (eds) Multinational Democracies (CUP Cambridge 2001) 201-21 at 201.

63 Eg during the 1995 referendum campaign, Canada threatened to veto any attempt by an independent Quebec to join NAFTA. See comments by Minister of Intergovernmental Affairs, Marcel Massé quoted in The Globe and Mail 10 Dec 1994.

64 This argument draws upon the power of institutions as set out by the 'new institutionalist' school of political science. BG Peters Institutional Theory in Political Science: The 'New Institutionalism (Continuum London 1999). 
Kingdom in 1980, and the failed constitutional initiatives of the draft Meech Lake Accord of 1987 and the draft Charlottetown Accord of 1992, where attempts were made to amend the Canadian constitution in order to meet at least some of Quebec's constitutional aspirations. While these initiatives remained credible, the Quebec nationalist elite approached the issue of constitutional reform in more incremental ways, and although many remained staunchly committed to seeking full statehood for Quebec irrespective of progress made in these constitutional negotiations, moderate nationalists turned to more radical 'sovereignty' options in 1995 largely as a result of the failure of these negotiations. The influence of existing institutions on contemporary constitutional praxis is also borne out simply in terms of the level, and sophistication, of constitutional activity in Canada in the 1980s and 1990s. In comparative terms, since the 1970 s, the constitutional demands of sub-state national societies in the UK and Spain have tended to be far more restrained that Quebec's and one reason for this is that nationalists in Catalonia and Scotland began their engagement with their respective host State from a position in which they lacked entrenched institutional power, whereas the ambition of Quebec nationalists was in large measure conditioned by the fact that they were seeking to build on an already very decentralized federal model. ${ }^{65}$

Therefore, in light of these three factors, and taking into account what has been said about the context of wider global and regional developments, it is possible to say that the agenda of sub-state nationalism is now being re-shaped within the context of two types of highly changeable and widely differentiated process. First, the over-arching spectre of external forces at supra-national and sectoral levels which to some extent refine the parameters within which constitutional change is negotiated and implemented; and secondly, the processes of negotiation and change themselves which, through both the development of a discourse common to all parties and the evolution of these engagements into substantive outcomes, set both the institutional context and the patterns of engagement, for their future evolution. ${ }^{66}$ It is within these two processes that sub-state nationalists develop ever more nuanced political goals which, in taking account of the complex shifts in institutional and behavioural reality at levels both internal and external to the State, and of the fluidity of identity patterns within the sub-state territory, serve to re-constitute nationalist aspirations. This can lead to the formulation of highly imaginative solutions for the perceived constitutional malaise of the sub-state national society in question, helping to

65 H Meadwell 'The Future of Quebec' (2001) Scottish Affairs 54-64 at 56.

$66 \mathrm{Eg}$ one way in which the legislative power of the devolved Scottish Parliament is limited is that it may not legislate incompatibly with either EC law or 'Convention rights' per the European Convention on Human Rights-(Scotland Act 1998, s 29(2)(d)). Debate on Scotland's future constitutional options will of necessity be framed within these strictures, which also represent the reality for any governmental authority within Europe today. C Himsworth 'Rights Versus Devolution' in T Campbell, K Ewing, and A Tomkins (eds) Sceptical Essays on Human Rights (OUP Oxford 2001); S Tierney 'Constitutionalising the Role of the Judge: Scotland and the New Order' (2001) 5 Edinburgh Law Review 49-72. 
ensure that these prescriptive remedies will be tempered by, and framed against, the realpolitik of this broader constitutional and political environment.

In this context it seems that the search for sophisticated models of accommodation within the State may in fact pose a more radical challenge to the State and its constitutional arrangements than does secession. Although substate national societies continue to identify with the host State, this should disguise neither the strength of sub-state nationalism nor the increasingly radical demands for a reconfiguration of the State constitution made by sub-state nationalist movements. For many citizens within sub-state national societies, these societies represent alternative demoi which should be recognized as constitutional co-equals by the constitution of the State. ${ }^{67}$ Such demands, if taken seriously by the State, can call into question many of the constitution's most profound self-understandings, including even the conception of unitary citizenship which has been an article of faith for State-building processes. ${ }^{68}$

By contrast, secession need not undermine the State's constitutional selfunderstanding in a significant way. Here it is helpful to consider the distinction between secession and revolution. On the one hand, secession occurs when a group removes itself and a piece of territory from the jurisdiction of the State. This differs from revolution: 'being aimed only at restricting the scope of the State's power, not dissolving it, [secession] does not, like revolution, require (though in fact it may result in) the overthrow of the government.' 69 Secession, therefore, does not necessarily pose any threat to the State's continuing constitutional authority over the remainder State, and accordingly may not require significant constitutional change beyond recognition, and then only de facto, of the act of secession. It simply involves a reduction in the size of territory over which the State and its constitution have jurisdiction; and in fact, through the withdrawal of a disgruntled minority, the political viability of the existing constitution may be consolidated. There is no doubt that secession can have a profound effect on the collective psychology of the remainder population, but purely in terms of the normative authority of the constitution, the effects need only be minimal. Neither, certainly, is it the case that a radical model of constitutional change designed to accommodate sub-state national societies is equivalent to revolution; once again there is no act of overthrowing the recognized government of the State. However, in their ever more imaginative manifestations, radical demands for constitutional recognition of the plurinational nature of the State do call into question fundamental assumptions about the allocation of normative authority within the constitution, particularly when they involve calls for 'shared sovereignty' by

\footnotetext{
67 F Requejo 'Democratic Legitimacy and National Pluralism' in Requejo (ed) Democracy and National Pluralism (Routledge London 2001) 157-77.

68 JH Carens Culture, Citizenship and Community (OUP Oxford 2000).

69 A Buchanan Secession: The Morality of Political Divorce from Fort Sumter to Lithuania and Quebec (Westview Press Boulder, CO 1991) 10.
} 
way of, for example, asymmetrical autonomy; ${ }^{70}$ sub-state veto rights within the State's constitutional amendment arrangements and/or other decisionmaking processes $;{ }^{71}$ and full and co-equal decision-making powers for substate national societies at the centre of the State. ${ }^{72}$ Although these demands stop short of calling for a break-up of the State, in seeking a radical reconfiguration of the State's constitution they do call for a conceptual revision of many of the central tenets of the State's dominant constitutional ideology in a way that secessionist demands do not.

\section{CONCLUSION}

The contemporary agendas of sub-state nationalist movements within Canada, Spain, and the UK are in many ways more complex, and in particular less 'secessionist', than is often assumed. In proposing radical constitutional change within the State, the dynamic of contemporary nationalism also impacts upon the traditional explanatory and prescriptive language through which constitutional arrangements are discussed. It is indeed inevitable that the increasing sophistication of sub-state nationalism, which shakes institutional statal certainties such as monistic conceptions of sovereignty, should also challenge existing constitutional theory and discourse. In other words, the challenge to State constitutions is no less a challenge to the way in which these constitutions are articulated and their fundamental principles debated. Therefore, constitutional language as much as political institutions is now also a point of contestation in plurinational States, as a consequence of perceptions within sub-state national societies that the reality of the plurinational State as a union of nations is not adequately represented in established constitutional norms and principles, or at least in the dominant interpretations and narrations of these norms and principles.

70 Catalan arguments for asymmetry within Spain are discussed by: L Moreno The Federalization of Spain (Frank Cass London 2001); F Requejo 'Federalism and the Quality of Democracy in Plurinational Contexts: Present Shortcomings and Possible Improvements' Workshop Paper, ECPR Joint Sessions of Workshops (ECPR Grenoble 2001); and ES Villadangos 'The coexistence between one state and several nationalities and regions: The Spanish Case' Workshop Paper, ECPR Workshop 23 (ECPR Mannheim 1999). For similar discussions re Canada, see: PM Leslie (n 37); P Resnick 'Toward a Multinational Federalism: Asymmetrical and Confederal Alternatives' in F Leslie Seidle (n 37) 71-94; and K McRoberts 'Canada and the multinational state' (2001) 34 Canadian Journal of Political Science 683-714.

71 Various experiments in this regard were attempted during the final years of the AustroHungarian empire, see Y Plasseraud 'How To Solve Cultural Identity Problems: Choose your own nation' Le Monde Diplomatique (2000). Such a right of veto has been a firm demand made by Quebec since patriation of the constitution from the UK through the Constitution Act 1982. K McRoberts Misconceiving Canada: The Struggle for National Unity (OUP Toronto 1997) 16-17; P Oliver 'Canada, Quebec and Constitutional Amendment' (1999) 49 University of Toronto Law Journal 519-610 at 534, and 544 nn 106-7.

72 Each of these demands appears in the Barcelona Declaration and in other proposals made by Catalan nationalist parties. Declaració de Barcelona (n 46); Roller (n 61) 211. 
These complex constitutional debates within the plurinational State also have implications for debates concerning sovereignty beyond the State. These implications, made manifest through the ways in which sub-state nationalism links to wider changes at sectoral and supra-state levels, are only beginning to play themselves out. What seems clear is that the full part which sub-state nationalism plays in the debate over globalization must be recognized if the changing nature of constitutionalism within modern, territorially diverse democracies is to be adequately understood. 
